INSTITUTE OF FORESTRY • BELGRADE

INSTITUT ZA ŠUMARSTVO • BEOGRAD

SUSTAINABLE FORESTRY

COLLECTION 73-74, 2016

ODRŽIVO ŠUMARSTVO

ZBORNIK RADOVA 73-74, 2016

UDK 630*453:551.583 (497.11-75 Golija) $=111$

Original scientific paper

\title{
THE CORRELATION BETWEEN THE CHANGES IN CLIMATE, THE INTENSITY OF SPRUCE DECLINE AND THE ABUNDANCE OF SPRUCE BARK BEETLES IN`GOLIJA`NATURE PARK
}

\author{
Mara TABAKOVIĆ-TOŠIĆ ${ }^{1}$, Marija MILOSAVLJEVIĆ ${ }^{2}$
}

\begin{abstract}
The paper presents the results of the research on the correlation between changes in microclimate, the intensity of spruce decline and active abundance of its two economically most significant harmful insects - eight-toothed (Ips typographus) and six-toothed (Pityogenes chalcographus) spruce bark beetles (Coleoptera: Curculionidae) in 'Golija' Nature Park whose pure and mixed conifer stands are dominated by spruce. The route method and ocular inspection were applied to study the presence and determine the intensity of spruce decline - both of individual trees and groups of trees in the management units of Dajićke planine, Kolješnica, Golija and Brusničke šume. Population dynamics of the two species of bark beetles and their active abundance were monitored by the method of trapping with barrier traps and the use of combined pheromone dispensers - PCIT Ecolure. Although the decline of individual conifer trees, primarily of spruce, had already been present in certain areas of these management units for several decades, it reached epidemic proportions due to extreme adverse climatic conditions in the period between 2011 and 2012 and culminated in 2015. A large number of physiologically-weakened trees raised the population levels of secondary harmful insect and the number or the active abundance of the two investigated species of insects reached a peak in 2016. The inability to take appropriate and timely remedial measures in the areas under stricter protection regimes greatly contributed to this situation.
\end{abstract}

Keywords: air temperature, precipitation, spruce decline, Ips typographus, Pityogenes chalcographus

\footnotetext{
${ }^{1}$ Mara Tabaković-Tošić PhD, Principal Research Fellow, Institute of Forestry, Belgrade

${ }^{2}$ Marija Milosavljević, master, Research Associate, Institute of Forestry, Belgrade
} 


\section{KORELACIJA IZMEĐU KLIMATSKIH PROMENA, INTENZITETA SUŠENJA SMRČE I BROJNOSTI POTKORNJAKA U PARKU PRIRODE GOLIJA}

Izvod: $U$ radu su prikazani rezultati istraživanja korelacije između mikroklimatskih promena, intenziteta sušenja smrče $i$ aktivne abundancije dve njene, ekonomski najznačajnije, štetne vrste insekata - osmozubog (Ips typographus) $i$ šestozubog (Pityogenes chalcographus) smrčinog potkornjaka (Coleoptera: Curculionidae) u području Parka prirode Golija, gde u četinarskim, čistim i mešovitim, sastojinama dominira smrča. U gazdinskim jedinicama Dajićke planine, Kolješnica, Golija i Brusničke šume, maršrutnim metodom, okularnim pregledom, istraženo je prisustvo i određen intenzitet sušenja pojedinačnih $i$ grupe stabala, a populaciona dinamika navedene dve vrste potkornjaka, odnosno njihova aktivna abundancija, praćena je metodom lova pomoću barijernih klopki, uz korišćenje kombinovanog feromonskog dispenzera - PCIT Ecolure. Iako je sušenje pojedinih stabala četinarskih vrsta drveća, prvenstveno smrče, u pojedinim područjima navedenih gazdinskih jedinica, prisutno već nekoliko decenija, ono, posle vrlo nepovoljnih, ekstremnih klimatskih uslova u periodu 2011-2012. godine, poprima epidemijski karakter, sa kulminacijom u 2015. Velika količina fiziološki oslabelih stabala, pozitivno je uticala na povećanje populacionih nivoa sekundarnih štetnih vrsta insekata, pa je u 2016. godini došlo do kulminacije brojnosti, odnosno aktivne abundancije istraživane dve vrste potkornjaka. Na ovakvo stanje dosta je uticala i nemogućnost i neblagovremenost preduzimanja odgovarajućih sanacionih mera u područjima pod strožijim režimima zaštite.

Ključne reči: temperatura vazduha, padavine, sušenje smrče, Ips typographus, Pityogenes chalcographus

\section{INTRODUCTION}

The epidemic decline of mainly coniferous indigenous forest tree species, as a recent phenomenon that most countries of Eastern and Central Europe are faced with, has reached unprecedented proportions in the Republic of Serbia. Numerous multidisciplinary research studies of this process have all proved that it is affected by a range of abiotic and biotic factors, one or several of which can become the most important ones at a certain time and space.

It has long been known that the stress caused by unfavorable climatic conditions has a major impact on the health status of forest stands. In some parts of the world, these impacts have led to sporadic, territorially-limited decline of the most vulnerable species. Therefore, many environmentalists have considered it to be normal, natural succession within the forest ecosystem (Auclair, 1993; Ciesla and Donaubauer, 1994; Swetnam and Betancourt, 1998). However, the situation has suddenly and dramatically changed in the last decade. Due to global warming and insufficient or irregular precipitation, a great number of countries have faced an epidemic decline of primarily coniferous tree species. Globally, the year of 2013 has been the fourth warmest year on record (1880), together with 2003. For instance, the average global temperature for the period of $1981-2010$ was $0.62^{\circ} \mathrm{C}$ above the average $\left(13.9^{\circ} \mathrm{C}\right)$. Annual precipitation sums were generally at the same level, but their temporal patterns were substantially changed, with a notable lack of rain during the growing period.

The interaction between insects and plants accounts for half of all relationships in nature, but natural conditions, such as extreme temperatures and 
excessive or poor rainfall, can also lead to a rapid increase in the number of some sensitive species.

When it comes to bark beetles, insects that would be the first to attack the trees weakened by different stress factors, the studies that have been conducted worldwide point to a variety of factors that can affect the high rate of their outbreak and attack. Some authors (Waring and Pitman, 1983; Christiansen and Bakke, 1988; Dutilleul et al., 2000; Økland and Christiansen, 2001; Wermelinger, 2004; Schumacher and Bugmann, 2006; Aukema et al., 2008, Tabaković-Tošić, 2014; Tabaković-Tošić and Milosavljević 2015, 2016) have listed the following factors as the most important causes of spruce bark beetle attack: prolonged drought and high daytime temperatures, excess and lack of rainfall, stand age and vitality of trees, tree aspect, UV radiation, ozone, lack of sanitary fellings and forest law, as well as elevation, excessive nitrogen, magnesium and phosphorus in the soil.

The large-scale decline of individual or groups of spruce trees, as the most common coniferous tree species in the growing stock of Serbia (Banković et al., 2009), has been recorded in all areas but its pure or mixed stands under special protection regime within the national parks of Kopaonik (Tabaković-Tošić, 2014; Tabaković-Tošić and Milosavljević, 2015) and Tara and in the nature parks of Stara Planina (Tabaković-Tošić, 2006) and Golija seem to be most affected. The epidemic decline of spruce forests in 'Golija' Nature Park has been going on for many years, but it reached massive proportions in the period from 2014 to 2016 .

The paper presents the results of the research on the correlation between the changes in microclimate, an increasingly intensive decline of mostly spruce trees in 'Golija' Nature Park and the active abundance of two economicallyimportant harmful insect species - eight-toothed, Ips typographus (Linnaeus, 1758)

and six-toothed, Pityogenes chalcographus (Linnaeus, 1761) (Coleoptera, Curculionidae, Scolytinae) bark beetles.

\section{MAIN CHARACTERISCTICS OF THE STUDY AREA}

Golija Mountain belongs to the extensive area of Stari Vlah-Raška Mountain Range or the inner zone of the Dinaric mountain range. It stretches from east to west, surrounded by the mountains of Jelica (north), Kopaonik, Čemerno, Radočelo (east), Javor (west), Zlatar, Jadovnik and Pešter plateau (south). There are three clearly distinguishable climate zones in the area: the mountain-valley zone (700 m a.s.1.) with a humid continental climate modified under the influence of the surrounding mountains, the transition zone (700-1300 $\mathrm{m}$ a.s.1.) with long, cold winters and short, cool summers, and the mountainous zone (over $1300 \mathrm{~m}$ a.s.1.) with harsh and cold winters and short and cool summers.

Mt. Golija, with a nature park of the same name (75,183 ha) and 'GolijaStudenica' Biosphere Reserve $(53,804 \mathrm{ha})$, is one of forest-richest mountains of Serbia (total of 89,000 ha; forest cover by municipalities: Ivanjica $49 \%$, Raška 46\%, Novi Pazar 48\% Kraljevo 49\% and Sjenica 20\%). According to the Spatial Plan of the special purpose area of 'Golija' Nature Park (2004), broadleaved species outnumber coniferous species, dominated by beech (accounting for $63.3 \%$ of the volume and $54.0 \%$ of the total volume increment), spruce (accounting for $19.5 \%$ of the total volume and $23.0 \%$ of the total increment), and with much lower 
shares of fir, Austrian pine, sessile oak and Turkey oak (from 1 to 7\%). Other tree species are represented by less than $1 \%$, but they also contribute to the biodiversity of the forest ecosystems.

The correlation between the intensity of the decline of individual trees and groups of trees and the active abundance of the two most important species of spruce bark beetles was studied in the forest stands of the following forest management units: Dajićke planine, Kolješnica, Golija and Brusničke šume (SE' Srbijašume', 'Golija Ivanjica` Forest estate, 'Ivanjica' Forest Administration).

\section{MATERIAL AND METHODS}

In the management units Dajićke planine, Kolješnica, Golija and Brusničke šume the route method and ocular inspection were applied to study the presence and determine the intensity of spruce decline - both of individual trees and groups of trees. The population dynamics of the eight-toothed, Ips typographus and sixtoothed, Pityogenes chalcographus bark beetles and their active abundance were monitored by the method of trapping with barrier traps and the use of combined pheromone dispensers - PCIT Ecolure (Figure 1).

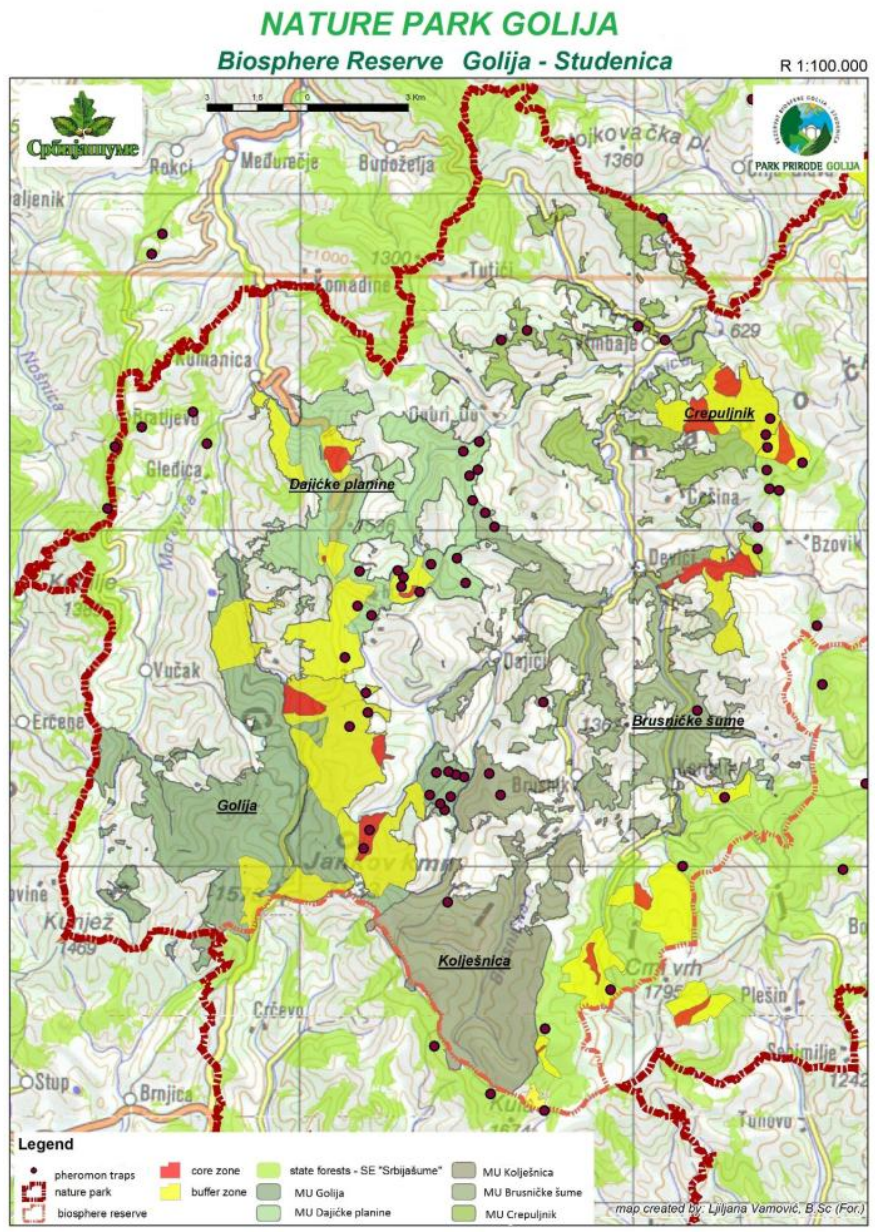

Figure 1. Distribution of pheromone traps in 'Golija` Nature Park with its 'GolijaStudenica`Biosphere Reserve. 


\section{RESULTS AND DISCUSSION}

The sporadic and modest decline of individual and small groups of trees of coniferous tree species, primarily spruce, has been present in the forest complexes of Mt. Golija for decades. The decline has been monitored within regular annual activities of SE 'Srbijašume', 'Golija Ivanjica` Forest Estate and the Department of Forest Protection of the Institute of Forestry in Belgrade. Since a part of this area was declared nature park and biosphere reserve and put under special protection regime, monitoring of the health state of the forest stands has been intensified, with special emphasis on the process of their decline.

In the FE 'Golija Ivanjica', especially in the FA 'Golijska reka' (Management units: Dajićke planine, Kolješnica, Golija and Brusničke šume), i.e. in the part of the nature park with conifer stands under the protection regime I, intensive decline of spruce trees began in 2012 and reached the strongest intensity in 2015 (sanitary felling of declined trees in $2014-12.579 \mathrm{~m}^{3}, 2015-18.502 \mathrm{~m}^{3}$ ). In 2016, despite sanitary measures, the decline was not stopped, but according to the wood volume marked for sanitary felling, $\left(13,000 \mathrm{~m}^{3}\right)$, its intensity was somewhat lower compared to the previous two years (Graph 1).

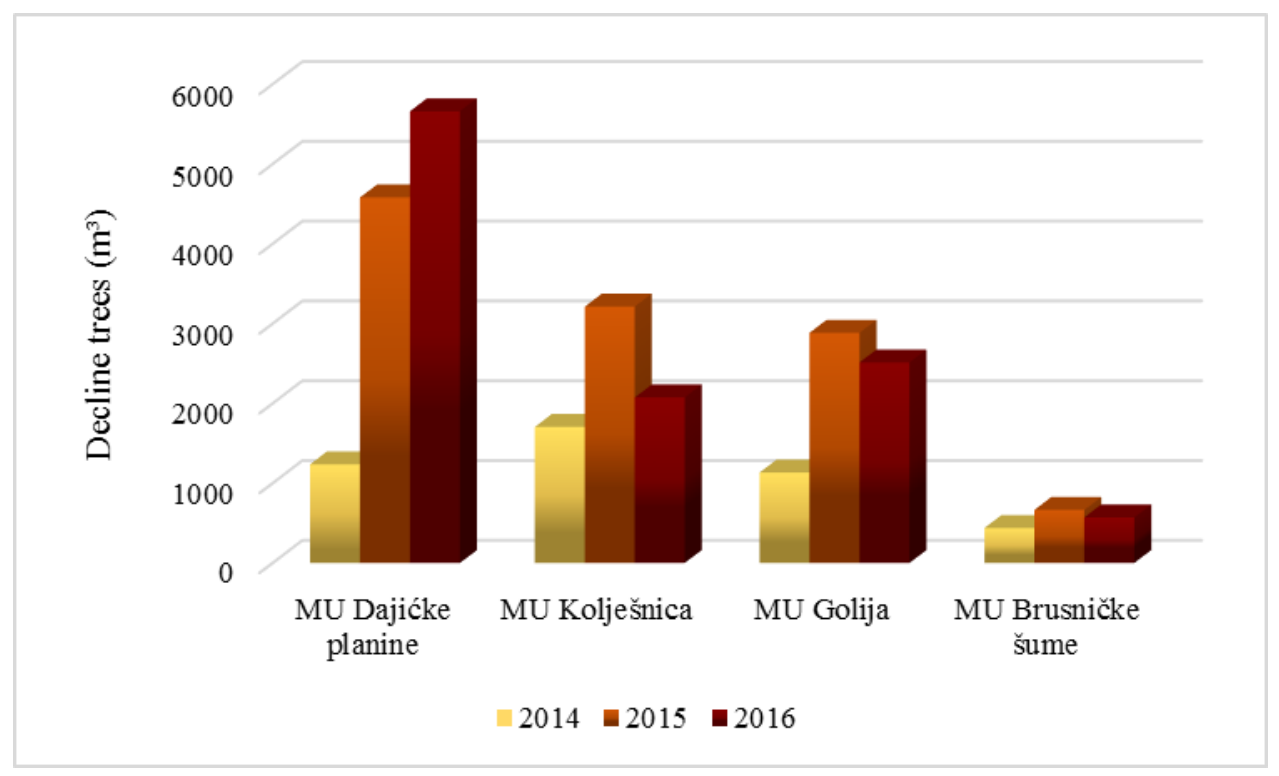

Figure 2. Spruce decline expressed as wood volume marked for sanitary felling in the period 2014-2016 in the study area of 'Golija`Nature Park.

Spruce decline reached a peak value in MU Dajićke planine (with 11,749 $\mathrm{m}^{3}$ of volume marked for felling in the period between 2014 and 2016), in 2016 (5, $661 \mathrm{~m}^{3}$ ) and in MU Kolješnica and MU Golija (with the volume marked for felling in the period between 2014 and 2016 of 6,994 and 6,532 $\mathrm{m}^{3}$ respectively) in 2015 $\left(3,213\right.$ and $\left.2,885 \mathrm{~m}^{3}\right)$. The lowest values were found in MU Brusničke šume (the total volume marked for sanitary felling amounted to 1,674 $\mathrm{m}^{3}$ ) (Figure 2). 
Drought-induced changes in trees, such as transpiration reduction and carbon assimilation, significantly reduce their natural, mostly chemical defense against attacks of various xylophagous species of insects and thus lower the threshold limit values.

To confirm the initial hypothesis of the research - a positive correlation between the changes in the microclimate, the decline of spruce trees and abundance of bark beetles, we thoroughly analyzed the climate - mean monthly air temperatures and monthly precipitation for the period 2006-2015. As there is not a main meteorological station on Mt. Golija, we used data of the main meteorological station on Zlatibor (Figure 3).
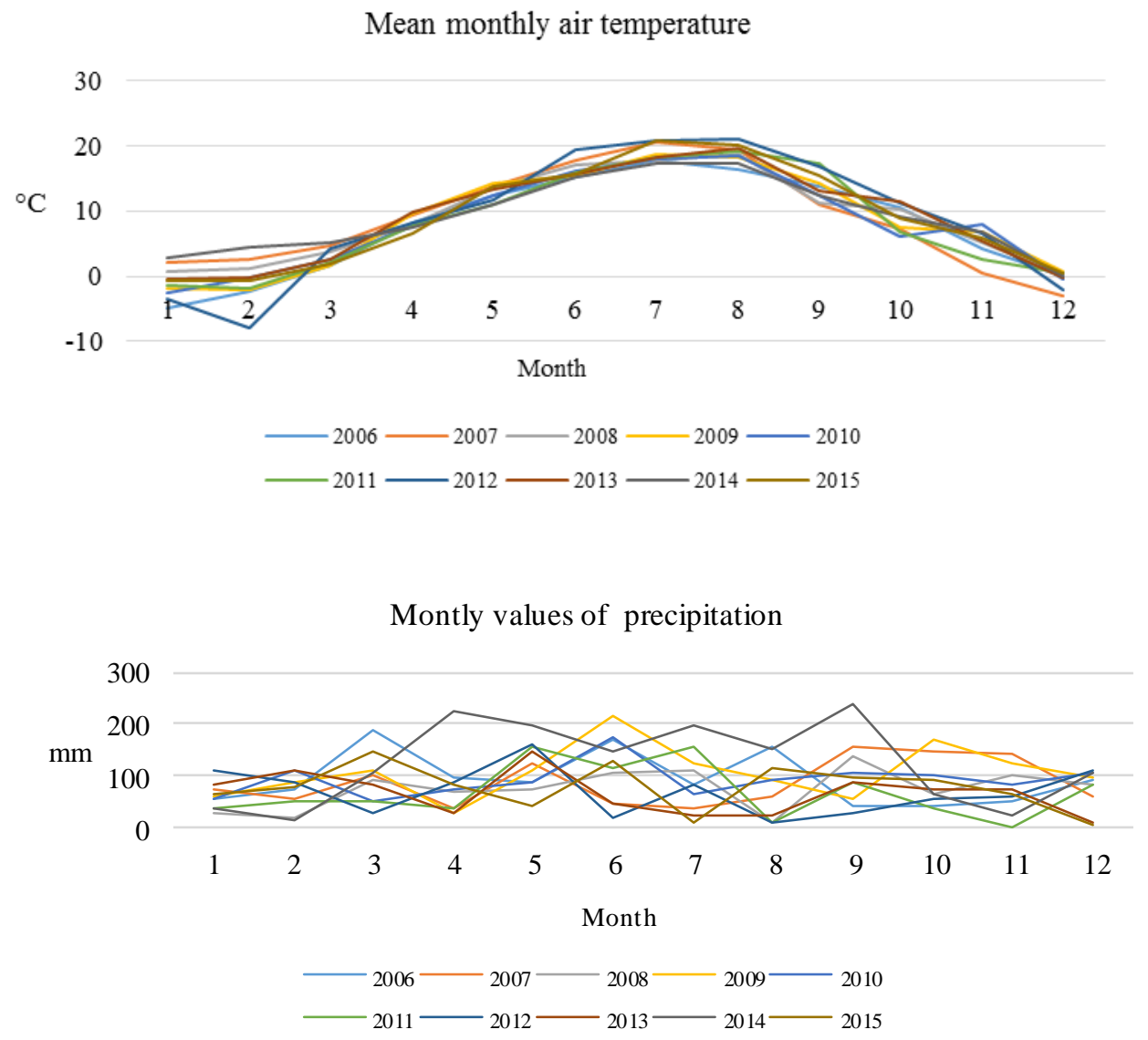

Figure 3. Monthly values of air temperature and precipitation for Zlatibor Meteorological Station ( $\alpha: 43^{\circ} 44^{\prime} N$; $\delta: 19^{\circ} 43^{\prime}$ E; the altitude of $1028 \mathrm{~m}$ ) for the period 2006-2015 
In the ten-year study period, the year of 2012 shows the greatest deviations - significantly higher mean monthly air temperatures in the growing period when the insects exert the most intense adverse effects on the coniferous species with shallow root plate system as in spruce. The onset of spruce forest decline in 'Golija' Nature Park was thus recorded in the year with the climate outside its optimum values (Figures 2, 3). The year of 2013 also recorded the smallest amounts of precipitation again in the growing period (April: the ten-year monthly average of $78 \mathrm{~mm}$, but only $31 \mathrm{~mm}$ in 2013; July: the ten-year monthly average of $89 \mathrm{~mm}$, but only $23 \mathrm{~mm}$ in 2013) (Figure 3).

A comparison of the results presented in Figures 2 and 3 clearly leads to the conclusion that there is a positive correlation between the intensified process of spruce decline and marked deviations of the two main meteorological parameters air temperature and precipitation in the growing period in the forest complexes of 'Golija` Nature Park.

Table 1. The number of beetle adults of one generation caught in one pheromone trap

\begin{tabular}{|c|c|c|c|c|c|c|c|}
\hline \multirow{3}{*}{$\begin{array}{c}\text { Management } \\
\text { unit }\end{array}$} & \multirow{3}{*}{ Year } & \multicolumn{6}{|c|}{ Trapped adults (N/pheromone trap) } \\
\hline & & \multicolumn{3}{|c|}{ Ips typographus } & \multicolumn{3}{|c|}{ Pityogenes chalcographus } \\
\hline & & minimum & maximum & average & minimum & maximum & average \\
\hline \multirow{3}{*}{$\begin{array}{l}\text { Dajićke } \\
\text { planine }\end{array}$} & 2014 & 15 & 316 & 110 & 21 & 369 & 130 \\
\hline & 2015 & 54 & 499 & 184 & 37 & 299 & 112 \\
\hline & 2016 & 21 & 1500 & 500 & 100 & 1150 & 383 \\
\hline \multirow{3}{*}{ Kolješnica } & 2014 & 13 & 137 & 50 & 19 & 106 & 42 \\
\hline & 2015 & 19 & 359 & 126 & 21 & 360 & 127 \\
\hline & 2016 & 303 & 7874 & 2625 & 54 & 1896 & 632 \\
\hline \multirow{3}{*}{ Golija } & 2014 & 31 & 742 & 258 & 15 & 710 & 242 \\
\hline & 2015 & 27 & 1103 & 377 & 18 & 1110 & 376 \\
\hline & 2016 & 38 & 4196 & 1398 & 406 & 3522 & 1174 \\
\hline \multirow{3}{*}{$\begin{array}{l}\text { Brusničke } \\
\text { šume }\end{array}$} & 2014 & 10 & 73 & 28 & 9 & 37 & 15 \\
\hline & 2015 & 3 & 126 & 43 & 15 & 125 & 47 \\
\hline & 2016 & 25 & 1085 & 362 & 116 & 1360 & 453 \\
\hline
\end{tabular}

In all the investigated management units in `Golija` Nature Park, the active abundance of the two most important species of spruce bark beetles, I. typographus and $P$. chalcographus has had a positive upward trend since 2014, with the maximum in 2016. The largest increase was recorded in the management units of Kolješnica and Golija (I. typographus 50:2625, 258:1398; P. chalographus 106:1896, 710: 3522) (Table 1). It should be noted that this trend will continue in 2017, unless we take all available measures of suppression aimed at reducing their abundance to normal, natural numbers. 
Figure 4. The ratio of the average number of bark beetles caught in a trap to the volume of declined trees marked for felling

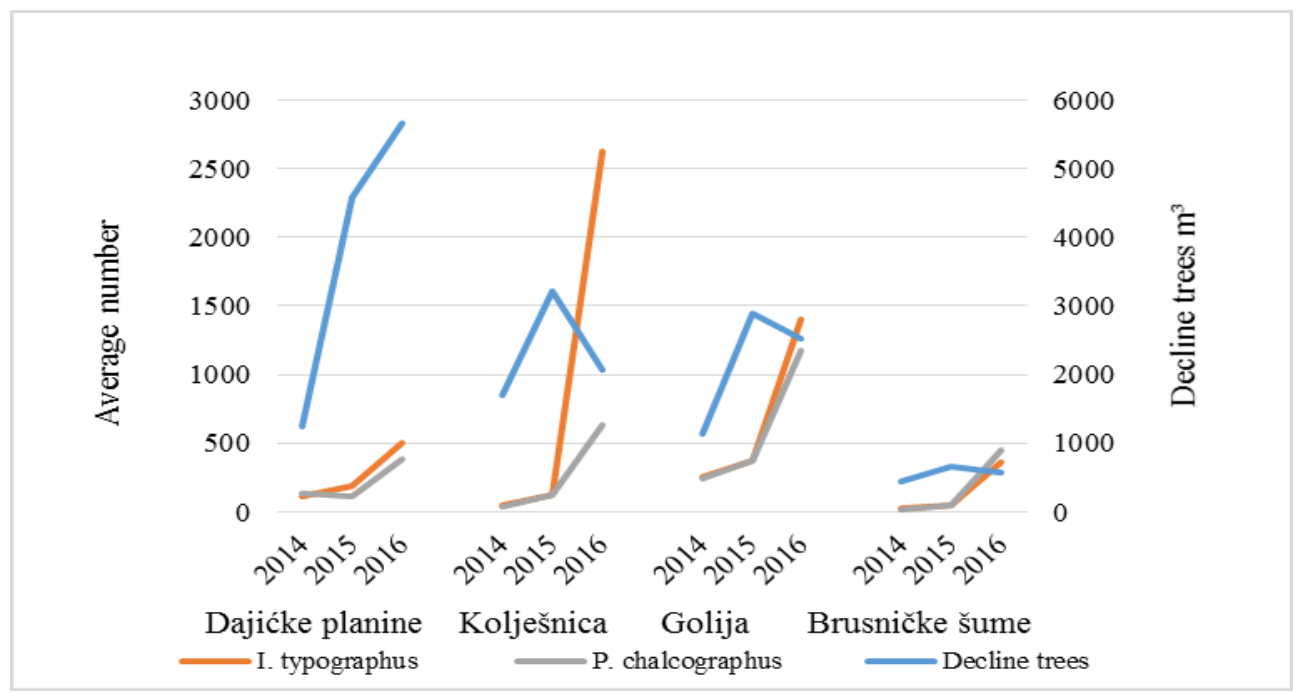

Dajićke planine management unit has a noticeable positive correlation between the spruce decline and the active abundance of $I$. typographus and $P$. chalcographus, i.e. in the three-year research period this management unit recorded an increase in the volume of declined trees marked for felling and in the abundance of the two species of bark beetles, which was not the case with the other three (Kolješnica, Golija and Brusničke šume), where the volume of declined trees marked for felling decreased, while the number of bark beetles increased dramatically (Figure 4). However, it is known that bark beetles attack living but severely physiologically-weakened trees, so it can be assumed that a positive correlation between these two parameters will be established in these management units, too.

\section{CONCLUSIONS}

The three-year study of the correlation between the changes in microclimate, the epidemic spruce decline and the increasing abundance of the two most important species of bark beetles, I. typographus and P. chalographus clearly points to a causal connection between them. Changes in microclimate, increasing average monthly air temperatures and a significant decrease in precipitation in the growing period contributed to the physiological weakening of spruce trees and initiated the process of their decline, thus increasing their susceptibility to the attack of the two species of bark beetles. The end result of this joint operation is the continuation of the epidemic decline of spruce stands in `Golija` Nature Park. 


\section{ACKNOWLEDGEMENTS}

These investigations were carried out as part of activities of public interest in the field of diagnostics of harmful organism and protection of the health of forest plants on the territory of the Republic of Serbia, excluding the territory of the Autonomous Province of Vojvodina in the period 2015-2019, financed by the Republic of Serbia through the Forest Directorate of the Ministry of Agriculture and Environmental Protection. The authors would particularly like to thank the colleagues from `Srbijašume` General Directorate and Golija Ivanjica Forest Estate on their the participation in the performance of the aforementioned tasks.

\section{REFERENCES}

Auclair, A.N.D. (1993): Extreme climatic fluctuations as a cause of forest dieback in the Pacific Rim. Water, Air and Soil Pollution, 66(3-4): 207-229.

Aukema, B.H., Carroll, A.L., Zheng, Y., Zhu, J., Raffa, K.F., Moore, D., Stahl, K., Taylor, S.W. (2008): Movement and outbreak populations of mountain pine beetle: influences of spatiotemporal patterns and climate. Ecography, 31: 348-358.

Banković, S., Medarević, M., Pantić, D., Petrović, N. (2009): National Forest Inventory of the Republic of Serbia - Forests of the Republic of Serbia. Ministry of Agriculture, Forestry and Water Management - Forest Directorate, Belgrade, Serbia, 1-244.

Bentz, B.J., Régnière, J., Fettig, C.J., Hansen, M., Hayes, J.L., Hicke, J.A., Rick, G., Kelsey, RG., Negrón, J., Seybold, S.J. (2010): Climate Change and Bark Beetles of the Western United States and Canada: Direct and Indirect Effects. BioScience, 60: 602-613.

Christiansen, E., A. Bakke, Eds. (1988): The spruce bark beetle of Eurasia. Dynamics of forest insect populations. Plenum Publishing Corporation.

Christensen, J.H., Hewitson, B., Busuioc, A., Chen, A., Gao, X., Held, I., Jones, R., Kolli, R.K., Kwon, W.-T., Laprise, R., Magaña Rueda, V., Mearns, L., Menéndez, C.G., Räisänen, J., Rinke, A., Sarr, A., Whetton, P. (2007): Regional climate projections. In Climate change 2007: the physical science basis. Contribution of Working Group I to the Fourth Assessment Report of the Intergovernmental Panel on Climate Change. Cambridge, UK \& New York, USA, Cambridge University Press.

Ciesla, W.M., Donaubauer, M.E. (1994): Decline and dieback of trees and forests: a global overview. FAO Forestry Paper No. 120. Rome, FAO.

Dutilleul, P., Stockwell, J.D., Frigon, D., Legendre, P. (2000): The Mantel test versus Pearson's correlation analysis: Assessment of the differences for biological and environmental studies. J. Agri. Biol. Env. Stat., 5: 131-150.

Dutilleul, P., Stockwell, J.D., Frigon, D., Legendre, P. (2000): The Mantel test versus Pearson's correlation analysis: assessment of the differences for biological and environmental studies. J Agric Biol Environ Stat., 5:131-150.

Jönsson, M.A., Harding, S., Bärring, L., Ravn, H.P. (2007): Impact of climate change on the population dynamics of Ips typographus in southern Sweden. Agricultural and Forest Meteorology, 146: 70-81.

Lindner, M., Garcia-Gonzalo, J., Kolström, M., Geen, T., Reguera, R., Maroschek, M., Seidl, R., Lexer, M.J., Netherer, S., Schopf, A., Kremer, A., Delzon, S., Barbati, A., 
Marchetti, M., Corona, P. (2008): Impacts of climate change on European forests and options for adaptation. Report to the European Commission Directorate-General for Agriculture and Rural Development. AGRI-2007-G4-06. Brussels, Belgium.

Økland, B., Christiansen, E. (2001): 22 years of spruce bark beetle records from southeastern Norway. Poster presentation at IUFRO-meeting Dynamics of Forest Insect Populations, Aberdeen 9-14 September.

Schumacher, S., Bugmann, H. (2006): The relative importance of climatic effects, wildfires and management for future forest landscape dynamics in the Swiss Alps. Global Change Biology, 12: 1435-1450.

Swetnam, T.W., Betancourt, J.L. (1998): Mesoscale disturbance and ecological response to decadal climatic variability in the American Southwest. Journal of Climate, 11: 3128-3147.

Tabaković-Tošić, M. (2006): Managament possibilities of Gypsy moth multiplication in forest ecosystems of protected areas. Proceedings of International Scientific Conference Management of forest ecosystems in national parks and other protected areas, p. 373-379, Jahorina-Tjentište, Bosnia and Herzegovina.

Tabaković-Tošić, M. (2014). The condition of tree crowns at the sample plots of level Ireliable or unreliable indicators of the vitality of main conifer species in Serbian forests. 3rd ICP Forests Scientific Conference "Impact of nitrogen deposition and ozone on the climate change mitigation potential and sustainability of European forests". Athens, Greece, May 26-28, 27.

Tabaković-Tošić, M., Milosavljević M. (2015): Impact of extreme weather conditions on the population dynamics of bark beetles in the forests of eastern Serbia. Sustainable Forestry, 71-72: 27-38.

Tabaković-Tošić, M., Milosavljević M. (2016): Spruce decline and an outbreak of spruce bark beetles in the natural forest stands of Kopaonik National Park. Proceedings of the XV Symposium of Plant Protection, Zlatibor, 28.11-02.12. 2016., pp.

Wermelinger, B. (2004): Ecology and management of the spruce bark beetle Ips typographus--a review of recent research. Forest Ecology and Management, 202(1-3): 6782.

Waring, R.H., Pitman, G.B. (1983) Physiological stress in lodgepole pine as a precursor for mountain pine beetle attack. Zeitschrift fur angewandte Entomologie 96: 265-270.

Spatial plan of Golija Special Purpose Nature Park - Strategy for the Protection and Development (2004). (Republic Agency for Spatial Planning of the Ministry of Tourism, Trade and Services, Eds.) 